\title{
Case study: back-analysis of a historical open pit highwall failure at a coal mine in Canada
}

\author{
C Clayton Tetra Tech Canada Inc., Canada \\ R Barnett Tetra Tech Canada Inc., Canada \\ M Slater Teck Resources Limited, Canada
}

\begin{abstract}
An open pit highwall up to $400 \mathrm{~m}$ in height is being planned at a coal mine in southeastern British Columbia, Canada. A geotechnical drilling program completed in 2016 identified that a thick (20-40 m), weak, soil-like coal seam will be exposed along the base of the proposed highwall slope. A historical highwall failure at an adjacent open pit occurred in 2011 where successful monitoring resulted in no personnel injury or equipment damage. Following the failure, a review identified that a thick seam of sheared coal at the base of the slope might have contributed significantly to the failure; however, no back-analysis was performed.

The discovery of a similar thick, friable, soil-like coal seam which will be exposed at the toe of the proposed highwall emphasised the need for a back-analysis of the historical slope failure to assist with understanding the previous failure relative to the design of the future wall. A back-analysis was then completed using limit equilibrium and finite element numerical modelling methods and included a review of monitoring, climate, and observational data. The finite element method best captured the site observations and data associated with the failure.

This paper presents the key findings from the back-analysis including the results of the finite element modelling, as well as conclusions which were relevant to the design of the proposed highwall slope.

Keywords: back-analysis, slope failure, slope deformation, weak coal, radar monitoring

\section{Introduction}

A coal mine located in southeastern British Columbia, Canada is planning a new open pit (P4 Pit) which will eventually expose a highwall up to $400 \mathrm{~m}$ in height (Figure 1). The site is part of a large phased open pit mine located on the western limb of the Greenhills syncline. Mining is undertaken on $15 \mathrm{~m}$ high single working benches. Highwalls and endwalls are mined using a standard benched wall design approach and are typically developed in a $30 \mathrm{~m}$ high double-bench configuration wherever the geotechnical conditions allow.

A geotechnical drilling program completed in 2016 within the proposed P4 Pit identified a thick (20-40 m) friable, soil-like coal seam which will be exposed along the base of the highwall slope. The coal seam location and thickness are similar to a seam exposed at the toe of the highwall in the adjacent P3 Pit, located along strike to the south. In 2011, a highwall failure occurred in P3 Pit when the thick coal seam was exposed at the base of the slope. At the time, a back-analysis of the failure was not completed. Since a similar thick soillike coal seam will be exposed at the toe of the proposed P4 Pit highwall, a back-analysis to understand the failure mechanism was completed to inform the design.
\end{abstract}




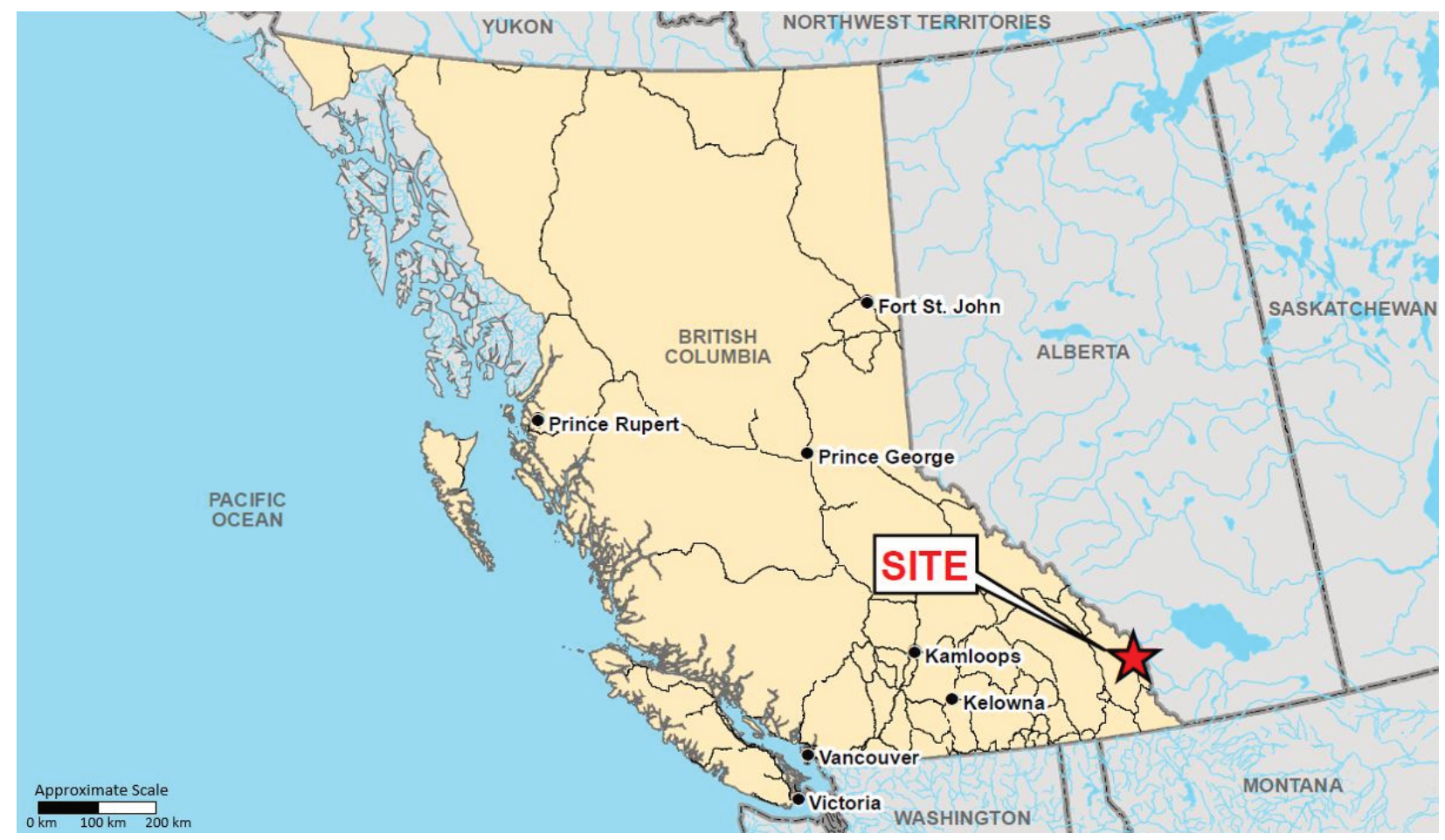

Figure 1 Site location

\section{Geological setting}

The region is contained within the Lewis Thrust Sheet, bounded to the west and east by the Bourgeau and Lewis Thrust Faults, respectively (Grieve \& Price 1987). The stratigraphy of the area consists of interbedded Jurassic age sedimentary units ranging from fine-grained mudstone, siltstone and shale, to coarser grained sandstone and conglomerate units. Coal seams interbedded within the sedimentary sequence are associated with the Mist Mountain and Morrissey Formations of the Kootenay Group. The Moose Mountain Sandstone, a strong and competent sandstone unit, underlies the Mist Mountain Formation coal beds. An idealised geological section through the P3 Pit highwall depicting each of these units and the key geological structures is shown in Figure 2. This figure also presents a stereonet showing the general geometric relationships between the various structural orientations.

North-south trending thrust faults associated with the tectonic movements have resulted in repetition of all or parts of the coal-bearing Mist Mountain Formation. The major structural features within the project site are two north-south trending asymmetric synclines with near horizontal to steeply dipping thrust faults and several high angle normal faults.

The rock fabric consists of north-south trending, continuous bedding dipping to the east between $20^{\circ}$ and $40^{\circ}$, with the dip angle varying with distance to the syncline axis. There are two mutually orthogonal but discontinuous joint sets. One orthogonal set strikes parallel to the strike of the bedding, while the other is perpendicular to bedding. In addition to the systematic rock structure, the presence of thrust faulting and more widely spaced major structural features also contribute to slope instability, depending on the location of these faults relative to the wall.

The regional hydrogeology is like other mountainous regions of British Columbia. Groundwater is recharged at higher elevations resulting in downward hydraulic gradients. Upward gradients are observed in valley bottoms where groundwater discharges to surface. The hydrogeology of the mine is complicated by the presence of structures and varying lithology. Groundwater seepage is observed at the contact with coal seams and the associated mudstones, which act as aquitards. 


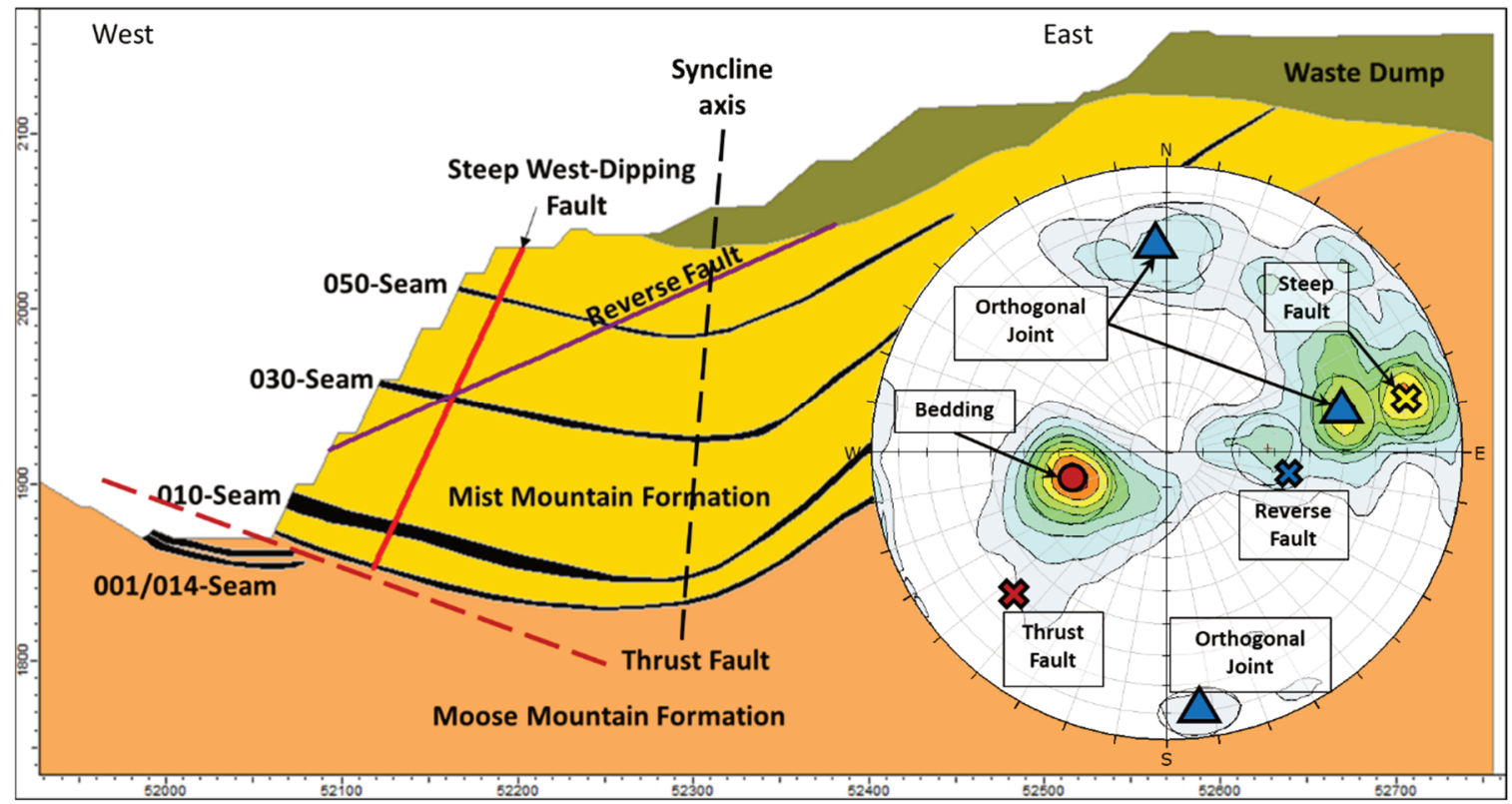

Figure 2 Idealised geological cross-section through the P3 highwall depicting key geological structures and geometry

\section{$3 \quad$ P3 Pit failure}

\subsection{Failure zone boundaries}

The total length of the failed portion of the P3 highwall slope is approximately $340 \mathrm{~m}$. The height of the failure zone is approximately $165 \mathrm{~m}$. Three main bounding structures interpreted as faults define the failure area, as shown in Figure 3. A north boundary fault trends into the east wall; an east boundary fault trends in a north-south direction behind the wall and is associated with the development of a large tension crack (Figure 4); and, a south boundary fault trends northeast-southwest, offsetting stratigraphy in the west footwall slope.

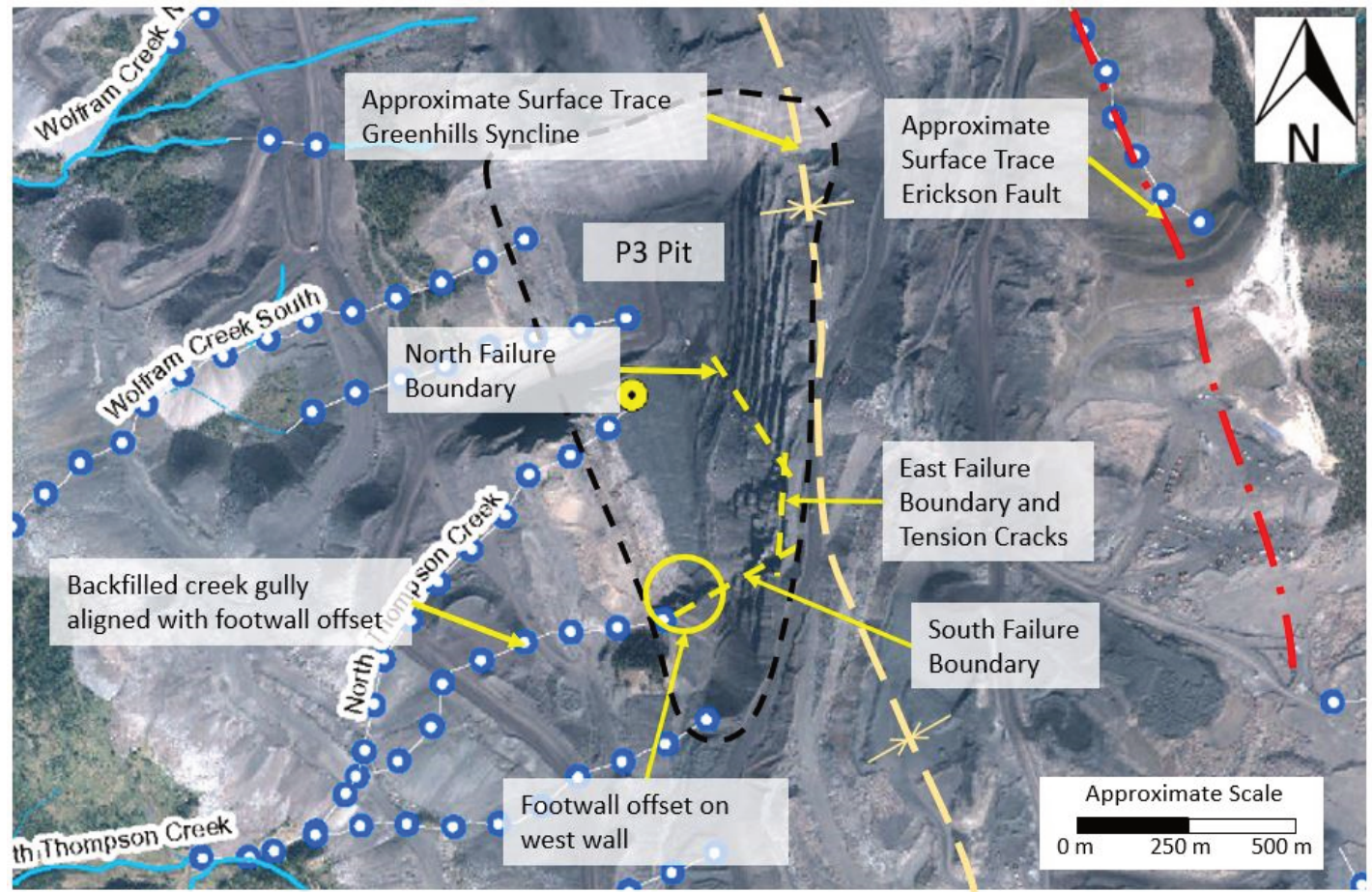

Figure 3 P3 Pit highwall failure boundaries and relevant major structures 


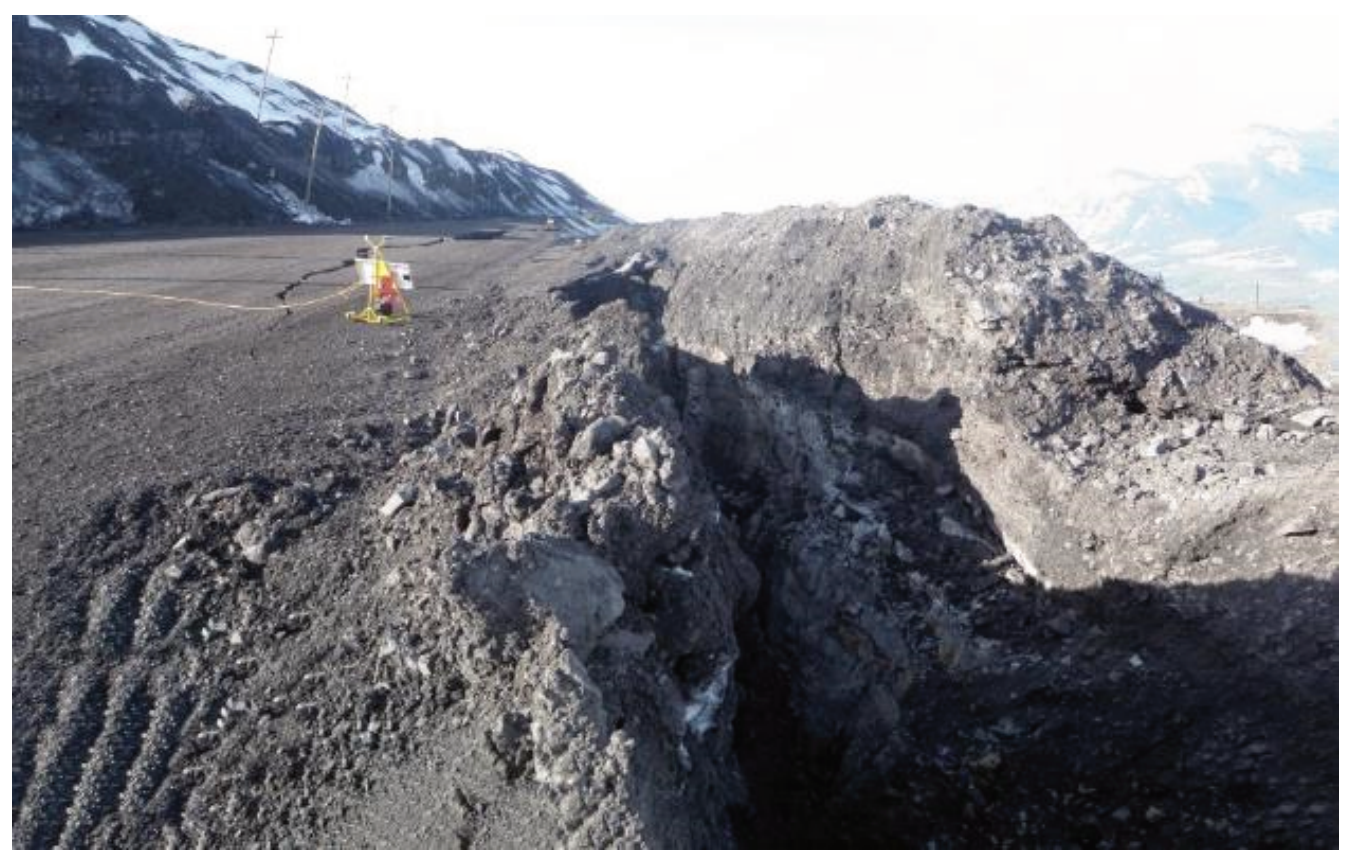

Figure 4 Tension cracks at crest of east highwall preceding failure

\subsection{Failure stages based on radar}

Based on review of the failure development chronology and the radar deformation patterns, the failure has been divided into a North Block and South Block, and generally occurred in three stages. The North Block is approximately $150 \mathrm{~m}$ long, while the South Block is approximately $190 \mathrm{~m}$ long.

Stage 1 (April 22/23 to May 3, 2011): The North and South Blocks deform uniformly at a constant velocity of approximately $2 \mathrm{~mm} / \mathrm{hr}$ across the face. Ravelling of the North Block face increases. An irregularly shaped decoupled boundary developed around the North and South Blocks as shown on Figure 5. Figure 6 shows the failed North Block.

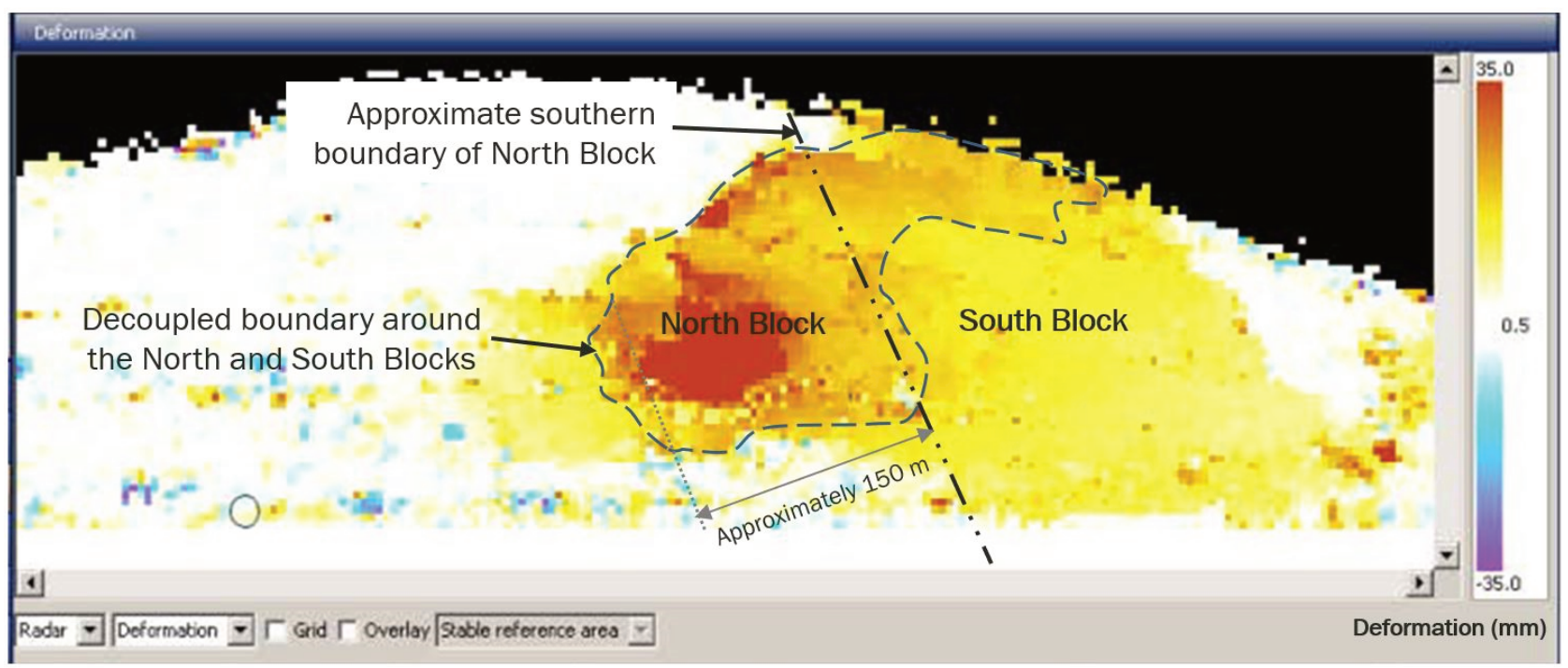

Figure 5 Slope radar image showing highwall deformation during Stage 1 between May 1, 2011 at 14:43 hrs and May 1, 2011 at 20:40 hrs. The decoupling of North and South Blocks is visible in the deformation contouring 


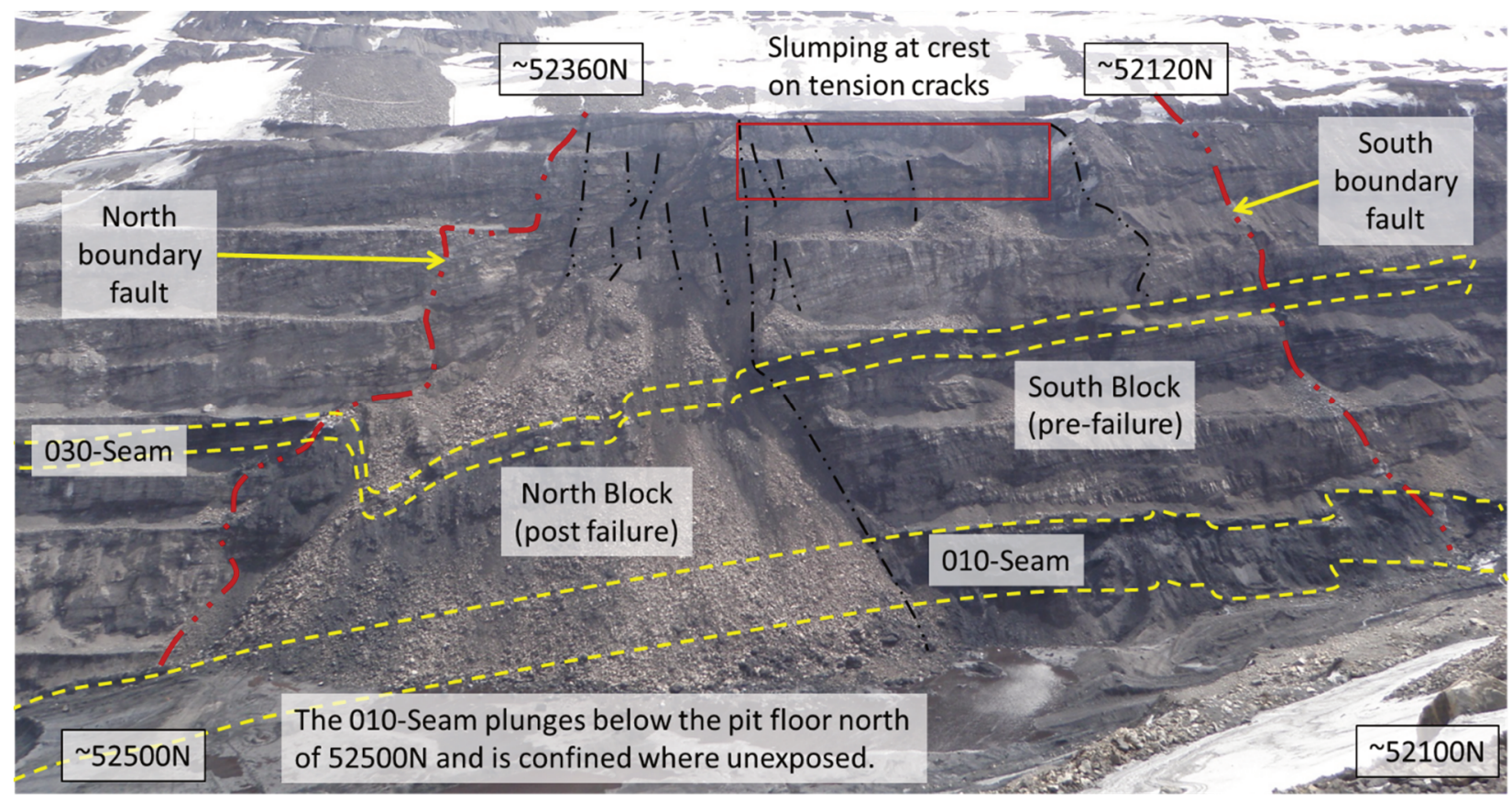

Figure 6 Highwall following North Block failure

Stage 2 (May 3 to 5, 2011): The surface ravelling stopped, but radar displacement velocities of the North and South Blocks accelerated to approximately $13 \mathrm{~mm} / \mathrm{hr}$. Horizontal 'banding' is observed on the radar associated with the benches, but also associated with the stronger stratigraphic units separating the coal seams, as show in Figure 7. Tension cracks formed in the road at the slope crest (Figure 4). The North Block failed on May 5, 2011, the upper benches slumped downwards, translated outwards, and broke up on the talus slope.

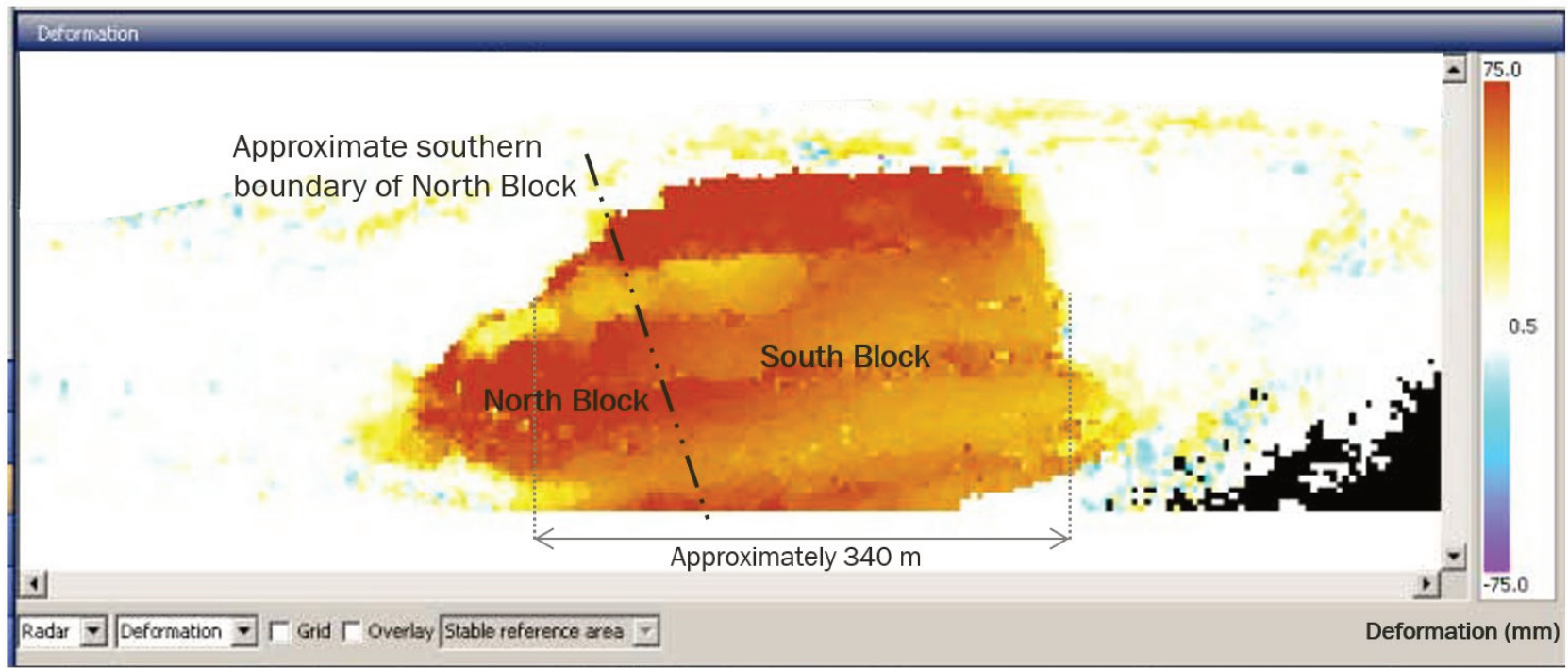

Figure 7 Slope radar image showing highwall deformation during Stage 2 between May 4, 2011 at 13:18 hrs and May 4, 2011 at 19:24 hrs. The Horizontal banding associated with deformation of the benches but also with the weaker coal seams separated by the more competent sandstone is visible

Hiatus (May 5 to 6, 2011, 1 day): No significant deformation was noted from May 5 to May 6, 2011.

Stage 3 (May 6 to 9, 2011): Displacement propagated along the wall, and from the toe of the slope upwards to the crest. The instantaneous velocity increased from approximately $6 \mathrm{~mm} / \mathrm{hr}$ at the north end, to 
approximately $25 \mathrm{~mm} / \mathrm{hr}$ at the south end. Horizontal deformation bands continued to develop, which were disrupted by vertical offsets forming discrete blocks, as shown in Figure 8. Figure 9 shows the final wall geometry after the failure.

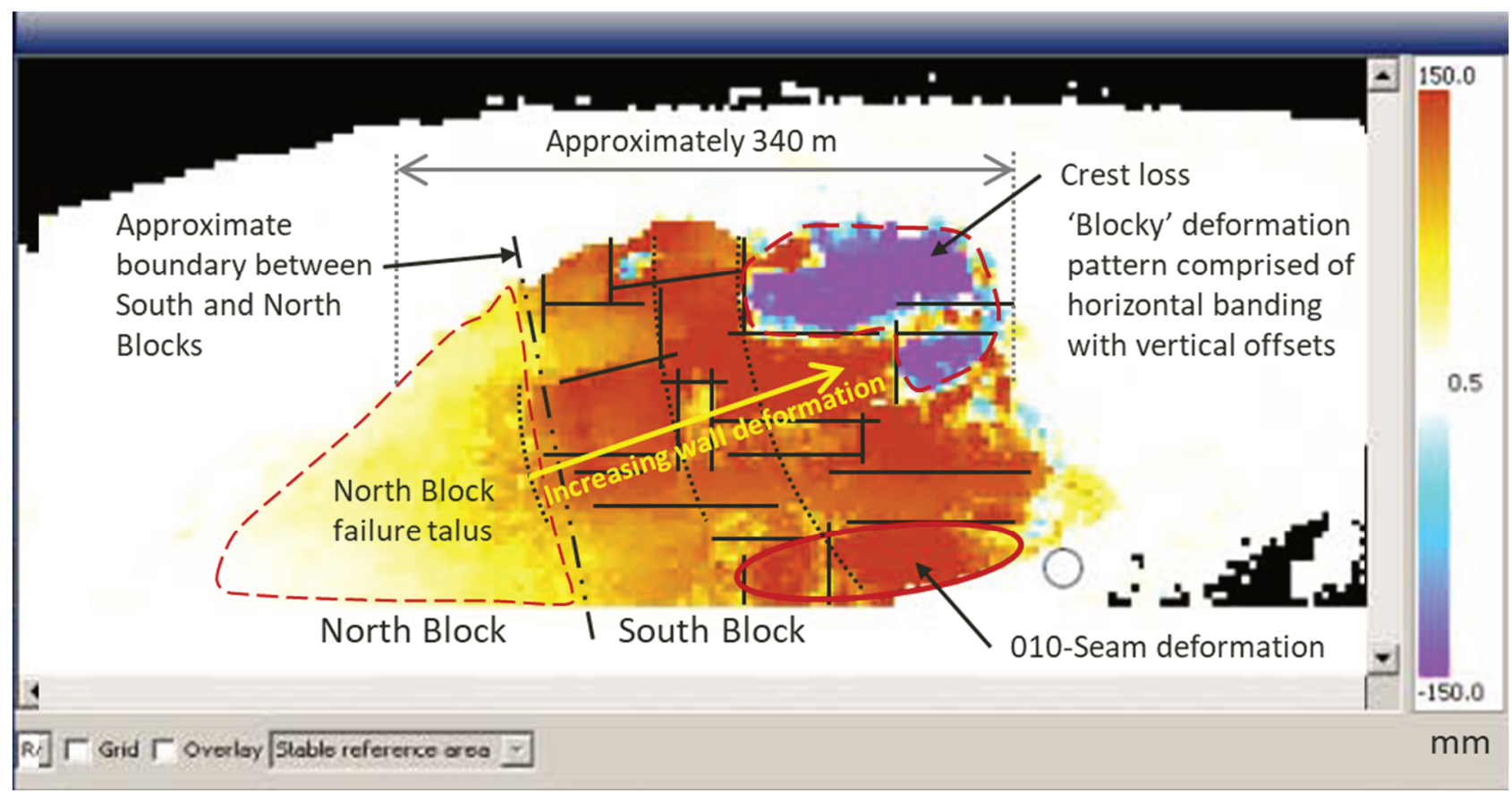

Figure 8 Slope radar image showing Stage 3 highwall deformation in South Block between May 8, 2011 at 00:14 hrs and May 8, 2011 at 06:08 hrs

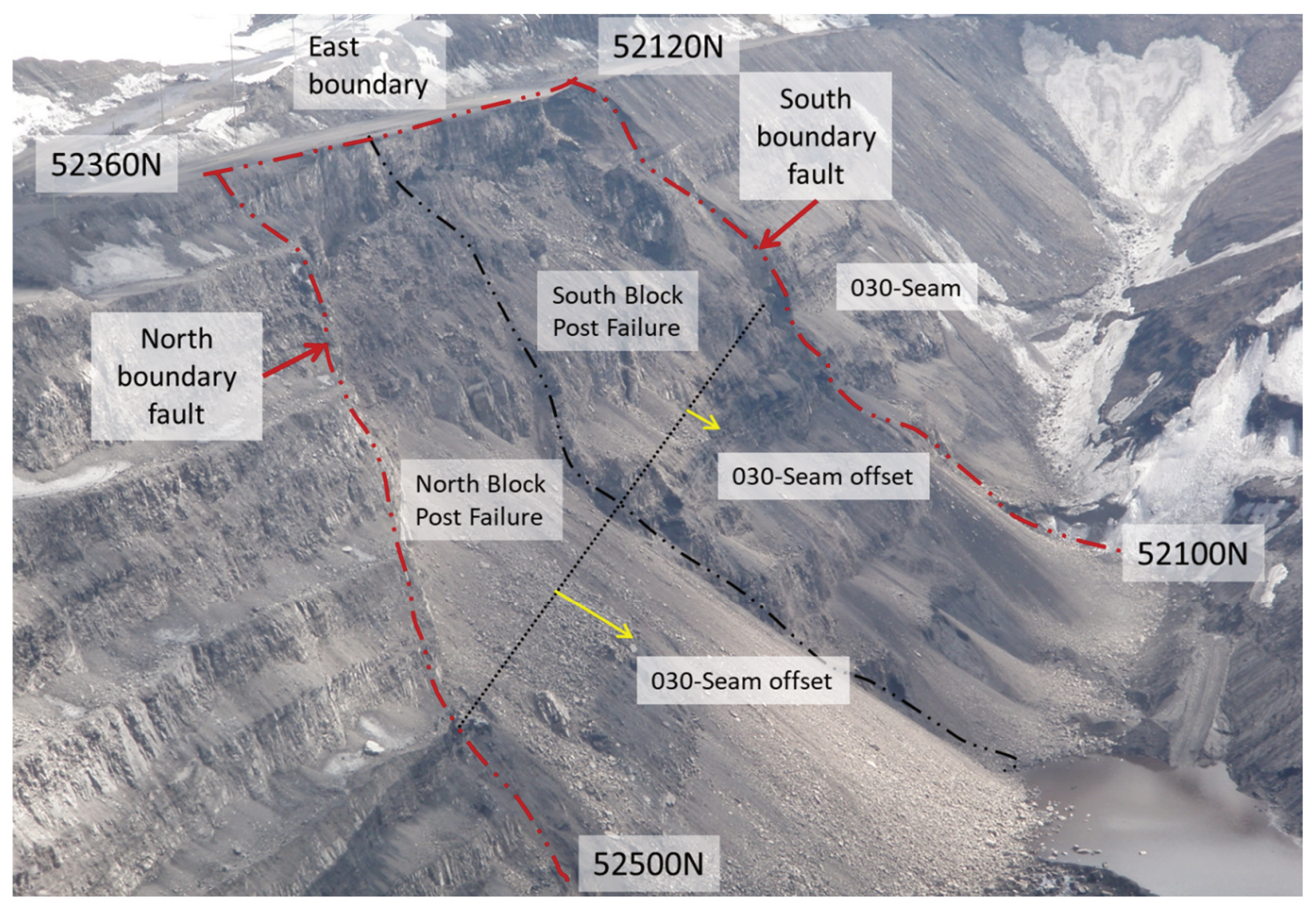

Figure 9 Highwall following South Block failure 


\subsection{Air temperature and precipitation data}

The air temperature and precipitation data during the weeks leading up to the failure are shown in Figure 10. These data suggest a possible correlation between the development of the failure and the date at which daily temperatures consistently remain above freezing during the transition from winter to spring. The onset of spring freshet likely released significant water from melting snow, and from the release of water from ground ice.

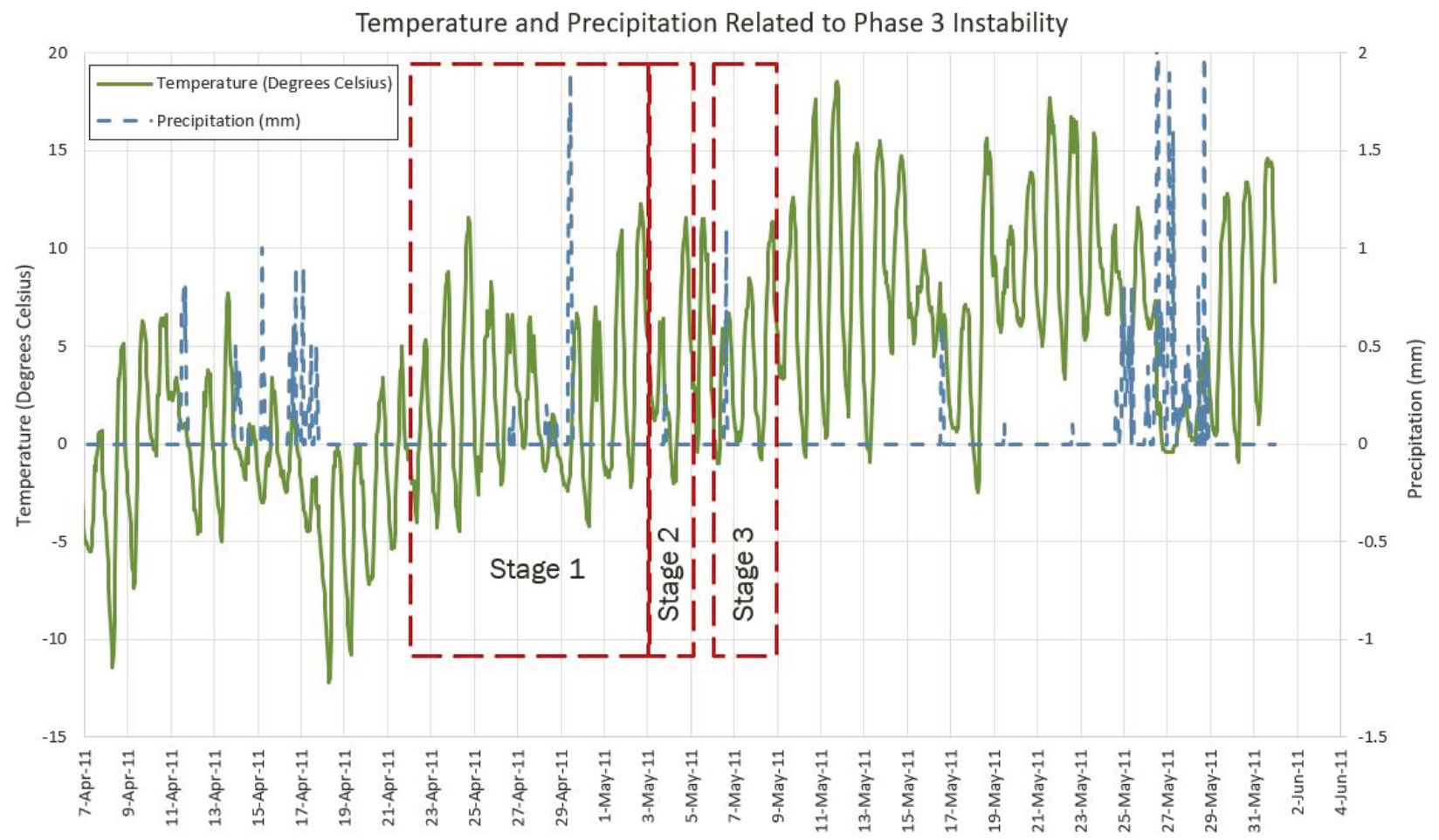

Figure 10 Temperature and precipitation data

\subsection{Seismic data}

The available seismic records for April 2011 leading up to the failure within a $500 \mathrm{~km}$ radius of the site were reviewed. These data show there were no significant seismic events preceding the failure.

\subsection{Monitoring data}

The northing, easting, and elevation data from four GPS monitoring points installed at the crest of the P3 Pit instability were reviewed, including the inverse velocity trends. Only GPS monitoring point GPS-105 showed the development of an inverse velocity trend prior to the failure. Post filtering of the one-hour GPS $3 \mathrm{D}$ velocity monitoring data indicated that averaging over 12 readings (i.e. 12-hour average slope distance velocities) provided the most appropriate amount of data filtering for observing trends. The data from GPS-105 suggest the inverse velocity data convergence commenced on approximately April 24, 2011 as shown on Figure 11. A linear projection of the trend suggested a failure date between May 5 and 6; however, as displacement rates increased closer to the projected failure date, a convex (concave-downward) inverse velocity trend developed beginning on May 3 and converging on a failure date of May 4.

Nine vibrating wire piezometers were installed in four boreholes located approximately $350-700 \mathrm{~m}$ north of the failure (Figure 12). There does not appear to be any significant change in pressure head leading up to the failure, although immediately following the failure there is a notable increase in groundwater pressure in several of the piezometers. It is difficult to determine if these are directly related to the failure itself or are responses associated with annual freshet cycles. 


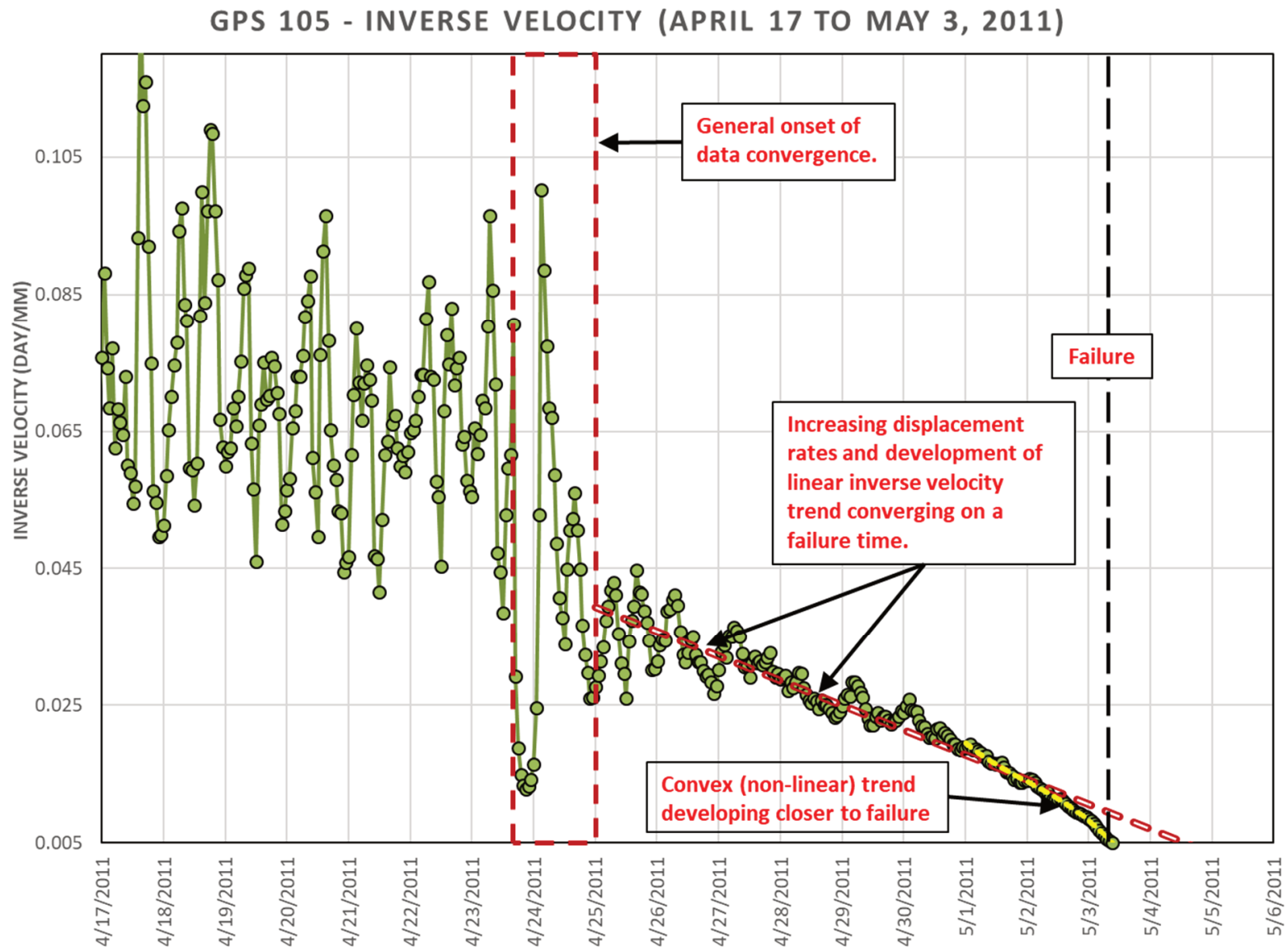

Figure 11 Inverse velocity graph of GPS Point 105 (GPS-105) data

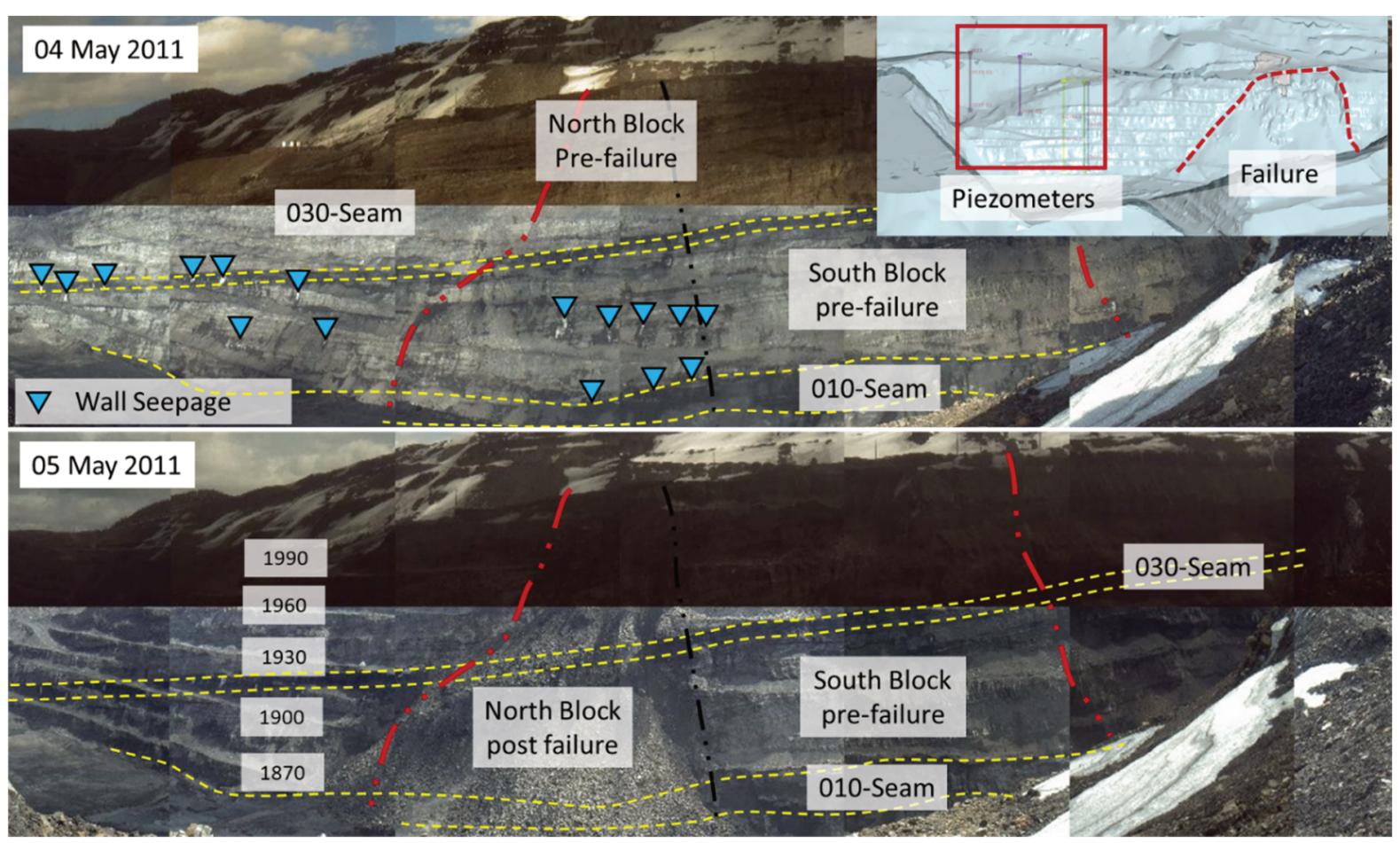

Figure 12 Seepage faces on coal seams and piezometer locations 


\subsection{Wall seepage observations}

Wall seepage is visible on photographs of the highwall from April 4, 2011 prior to the failure (Figure 12). Seepage is visible within the coal measure rock midway between the 010-Seam and the 030-Seam, as well as within the 030-Seam (the approximate coal seam locations are shown on Figure 12). The locations of seeps on the wall are consistent with the available vibrating wire piezometer data which suggest that the coal, and associated finer grained sediments are acting as aquitards.

\section{$4 \quad$ Engineering geological model}

The engineering geological model for the P3 Pit highwall was developed using available information for the P3 Pit, and incorporated relevant information collected during the P4 Pit east highwall geotechnical drilling investigation.

\subsection{Geology and structure}

The major structural features are described in Section 2 and are shown stereographically on Figure 2. These are the continuous bedding, major and minor joint sets, and major fault structures. Highwall bench performance is generally controlled by the two orthogonal and variably continuous joint sets. Overall slope performance is often controlled by the presence or absence of adversely oriented major fault structures, and by their interaction with the more systematic rock structure (bedding and systematic joint sets).

\subsection{Unconfined compressive strength}

Estimates of unconfined compressive strength (UCS) for the Mist Mountain, Moose Mountain and competent coal are based on available UCS test results. The UCS data are summarised in Table 1.

Table $1 \quad$ Summary of unconfined compressive strength (UCS) data

\begin{tabular}{|c|c|c|c|c|c|c|}
\hline \multirow[b]{2}{*}{ Material type } & \multicolumn{6}{|c|}{ UCS (MPa) } \\
\hline & Minimum & Maximum & Mean & $\begin{array}{l}\text { Standard } \\
\text { deviation }\end{array}$ & $\begin{array}{c}\text { 35th } \\
\text { percentile }\end{array}$ & Count \\
\hline Mist Mountain & 27.1 & 177.4 & 92.4 & 37.9 & 71.7 & 95 \\
\hline Moose Mountain & 32.8 & 177.4 & 117.0 & 37.6 & 109.5 & 35 \\
\hline $\begin{array}{l}\text { Competent coal: } \\
\text { excluding weak coal seam }\end{array}$ & 3.6 & 20.8 & 7.6 & 5.1 & 5.7 & 11 \\
\hline
\end{tabular}

\subsection{Rock mass rating}

The rock at the project site is classified according to the Council for Scientific and Industrial Research Rock Mass Rating $\left(\mathrm{RMR}_{76}\right.$ ) classification system (Bieniawski 1976). The $\mathrm{RMR}_{76}$ data are summarised in Table 2. 
Table 2 Summary of $\mathrm{RMR}_{76}$ classification

\begin{tabular}{|c|c|c|c|c|c|}
\hline & \multicolumn{4}{|c|}{$\mathrm{RMR}_{76}$} & \multirow{2}{*}{$\begin{array}{c}\text { Rock quality } \\
\text { classification } \\
\text { (average RMR } \text { RM6 }^{\text {) }}\end{array}$} \\
\hline & Minimum & Maximum & Mean & 35th percentile & \\
\hline Mist Mountain & 18 & 97 & 65 & 59 & Good \\
\hline Moose Mountain & 35 & 87 & 69 & 69 & Good \\
\hline $\begin{array}{l}\text { Competent coal: excluding } \\
\text { weak coal seam }\end{array}$ & 18 & 82 & 41 & 34 & Poor \\
\hline Weak coal & 18 & 54 & 28 & 18 & Poor to N/A (soil) \\
\hline Faults & 18 & 70 & 38 & 31 & Poor \\
\hline
\end{tabular}

\section{$5 \quad$ Weak coal seam characterisation}

\subsection{Drilling and sampling}

A geotechnical drilling investigation was completed in the P4 Pit highwall in 2016 using standard triple tube HQ3 sized coring. Recovery of the highly sheared, weak, deformable, and highly friable coal in the 010-Seam was accomplished using rigid plastic liners in place of the metal split tubes. The coal was extracted directly into the plastic liners and the ends were capped and waxed to preserve natural moisture content. The soil-like consistency of the 010-Seam is distinct from the surrounding rock mass and from other site coal seams.

Field strength estimates for the weak coal seam using the International Society for Rock Mechanics (ISRM) Soil and Rock Strength Classification typically ranged from ' $\mathrm{S} 3$ ' to ' $\mathrm{RO}$ ', which classify as 'firm soil' to 'extremely weak rock'.

\subsection{Coal seam laboratory testing}

A laboratory testing program was completed on coal from the seam to better characterise its strength and deformation characteristics including direct shear testing, drained and undrained triaxial compression testing, and undrained triaxial extension testing. A detailed description of the laboratory testing program, and discussion of results, is described in Barnett et al. (2017).

\section{$6 \quad$ Finite element modelling}

A cross-section through the centre of the P3 Pit instability area was analysed.

\subsection{General model setup}

The finite element (FE) software RS2 version 9.023 (Rocscience Inc. 2017) was used for the two-dimensional, plane strain, effective stress analyses to assess the contribution of deformation in the weak coal seam to failure initiation. The model was run in stages to simulate the changes in stress during excavation of the highwall. A joint network was used to represent the bedding and major joint set within the Mist Mountain unit. Estimates of joint spacing were based on the P4 Pit drilling investigation data. A horizontal effective stress to vertical effective stress ratio of $K_{0}=1.6$ was selected for the base case based on a literature review of typical stress conditions at coal mines in Western North America. Piezometric surfaces were estimated for each phase in the FE model based on the topography and available hydrogeological data for the site. A shear strength reduction (SSR) analysis was used to estimate the critical strength reduction factor (SRF) for the P3 Pit highwall.

The rock mass strength models used for the RS2 analysis are presented in Table 3. Since the Mist Mountain unit was modelled using Generalised Hoek-Brown parameters, the reduction in rock mass strength due to 
the systematic rock structure was incorporated into the Generalised Hoek-Brown parameters. The incorporation of a joint network into the RS2 model was intended to capture the influence of systematic structural anisotropy on the failure mechanism of the overall slope by including the intermediate scale joints in the model with a higher spacing and length (Elmo et al. 2018).

Table 3 Summary of material strength functions used in finite element models

\begin{tabular}{ll}
\hline Material & Strength function \\
\hline Mist Mountain & Generalised Hoek-Brown with a joint network \\
Joints/bedding/faults & Mohr-Coulomb \\
Coal seams & Mohr-Coulomb \\
Moose Mountain & Generalised Hoek-Brown \\
Waste dump & Mohr-Coulomb \\
\hline
\end{tabular}

The strength parameters for the modelling are summarised in Tables 4 and 5.

Table 4 Summary of rock mass strength input parameters

\begin{tabular}{lcccccccc}
\hline Rock type & $\begin{array}{c}\text { Unit weight } \\
\left(\mathbf{k N} / \mathbf{m}^{\mathbf{3}}\right)\end{array}$ & $\begin{array}{c}\text { UCS } \\
(\mathbf{M P a})\end{array}$ & $\begin{array}{c}\mathrm{RMR}_{\mathbf{7 6}} \\
(\mathbf{G S I})\end{array}$ & $\mathbf{m}_{\mathbf{i}}$ & $\begin{array}{c}\text { Disturbance } \\
\text { factor (D) }\end{array}$ & \multicolumn{2}{c}{ Generalised Hoek-Brown } \\
\hline Mist Mountain & 26 & 72 & 59 & 9 & 0 & 0.011 & 2.081 & 0.503 \\
$\begin{array}{l}\text { Disturbed Mist } \\
\begin{array}{l}\text { Mountain } \\
\text { Moose Mountain }\end{array}\end{array}$ & 26 & 72 & 59 & 9 & 0.7 & 0.003 & 0.946 & 0.503 \\
\hline
\end{tabular}

Table 5 Summary of finite element Mohr-Coulomb input parameters

\begin{tabular}{|c|c|c|c|c|c|}
\hline \multirow[b]{2}{*}{ Material } & \multirow{2}{*}{$\begin{array}{c}\text { Unit } \\
\text { weight } \\
\left(\mathrm{kN} / \mathrm{m}^{3}\right)\end{array}$} & \multicolumn{2}{|c|}{ Peak } & \multicolumn{2}{|c|}{ Residual } \\
\hline & & $\begin{array}{l}\text { Friction } \\
\text { angle }\left({ }^{\circ}\right)\end{array}$ & $\begin{array}{c}\text { Cohesion } \\
(\mathrm{kPa})\end{array}$ & $\begin{array}{l}\text { Friction } \\
\text { angle }\left({ }^{\circ}\right)\end{array}$ & $\begin{array}{c}\text { Cohesion } \\
\text { (kPa) }\end{array}$ \\
\hline Competent coal seams & 17 & 37 & 360 & 28 & 50 \\
\hline Weak coal seam & 17 & 35 & 300 & 23 & 50 \\
\hline Waste dump & 20 & 40 & 0 & $\mathrm{~N} / \mathrm{A}$ & $\mathrm{N} / \mathrm{A}$ \\
\hline
\end{tabular}

Elastic-perfectly plastic conditions were applied to the material modelled using the Generalised Hoek-Brown strength function (i.e. the same peak and residual values were applied). Peak and residual properties were assigned to the material modelled using Mohr-Coulomb properties based on the laboratory testing results, with peak properties initially applied followed by residual values after material yielding occurred. A nominal cohesion value of $50 \mathrm{kPa}$ cohesion was applied to the coal to improve numerical stability and convergence. The $35^{\text {th }}$ percentile values for UCS and $\mathrm{RMR}_{76}$ were used in the modelling to account for heterogeneity in the rock mass. The waste dump material was modelled as an elastic (non-yielding) material to mitigate numerical instability associated with yielding at shallow depths on the waste dump slopes.

Three cases which incorporated different joint networks and discrete faults were considered which are described in Table 6. 
Table 6 Discontinuity combinations for finite element modelling

\begin{tabular}{|c|c|c|c|}
\hline Case & Discontinuities considered & Set name & Comments \\
\hline 1 & Bedding (BD) & $\mathrm{BD}$ & - \\
\hline 1 & $\begin{array}{l}\text { Orthogonal joint set parallel to } \\
\text { bedding }\end{array}$ & Set NS-J(a) & - \\
\hline 1 & Discrete west dipping fault & N/A & - \\
\hline 2 & $\begin{array}{l}\text { Orthogonal joint set parallel to } \\
\text { bedding }\end{array}$ & Set NS-J(a) & $\begin{array}{l}\text { Out-dipping structures included as a } \\
\text { ubiquitous set with a spacing of } 20 \mathrm{~m}\end{array}$ \\
\hline 2 & Discrete west dipping fault & N/A & \multirow{2}{*}{$\begin{array}{l}\text { Unable to achieve adequate mesh quality } \\
\text { when bedding is included }\end{array}$} \\
\hline 2 & Reverse faults & Set RF & \\
\hline 3 & $\begin{array}{l}\text { Orthogonal joint set parallel to } \\
\text { bedding }\end{array}$ & Set NS-J(a) & $\begin{array}{l}\text { Out-dipping structure included as a } \\
\text { discrete feature daylighting in the }\end{array}$ \\
\hline 3 & Discrete west dipping fault & N/A & 010-Seam \\
\hline 3 & Discrete reverse fault & N/A & $\begin{array}{l}\text { Unable to achieve adequate mesh quality } \\
\text { when bedding is included }\end{array}$ \\
\hline
\end{tabular}

The peak and residual shear strength values outlined in Table 7 were used in the models, where residual strength properties were applied following yielding of the discontinuities. A nominal cohesion value of $30 \mathrm{kPa}$ was applied to the bedding, joints and faults to improve numerical stability and convergence.

Table $7 \quad$ Finite element discontinuity shear strength properties

\begin{tabular}{lcccc}
\hline Discontinuity type & \multicolumn{2}{c}{ Peak } & \multicolumn{2}{c}{ Residual } \\
& $\begin{array}{c}\text { Friction } \\
\text { angle }\left(^{\circ}\right)\end{array}$ & $\begin{array}{c}\text { Cohesion } \\
\text { (kPa) }\end{array}$ & $\begin{array}{c}\text { Friction } \\
\text { angle }\left(^{\circ}\right)\end{array}$ & $\begin{array}{c}\text { Cohesion } \\
\text { (kPa) }\end{array}$ \\
\hline Bedding & 31 & 30 & 24 & 30 \\
Joints & 30 & 30 & 26 & 30 \\
Large displacement faults & 17 & 30 & 17 & 30 \\
Low displacement faults (set RF) & 23 & 30 & 23 & 30 \\
\hline
\end{tabular}

Table 8 summarises the intact and rock mass deformation properties used in modelling.

Table $8 \quad$ Summary of model deformation properties

\begin{tabular}{lccc}
\hline Material & $\begin{array}{c}\text { Intact Young's } \\
\text { modulus (GPa) }\end{array}$ & $\begin{array}{c}\text { Rock mass deformation } \\
\text { modulus (GPa) }\end{array}$ & $\begin{array}{c}\text { Poisson's } \\
\text { ratio }\end{array}$ \\
\hline Mist Mountain & 35.1 & 17.5 & 0.26 \\
Disturbed Mist Mountain & 35.1 & 6.6 & 0.26 \\
Moose Mountain & 33.8 & 2.4 & 0.25 \\
Competent coal seams & 3.5 & N/A & 0.32 \\
Weak coal seam & 3.5 (minimum & N/A & 0.32 \\
Waste dump & for convergence) & N/A & 0.3 \\
\hline
\end{tabular}


For the materials modelled using the Generalised Hoek-Brown strength model, the intact Young's moduli were used to estimate rock mass deformation moduli.

\section{$7 \quad$ Finite element results}

To assess the impact of the 010-Seam deformation on overall wall stability, models were first completed to determine the SRF of the slope prior to exposure of the seam at the toe. Models were then run to assess the effect of exposing the weak coal seam at the toe of the slope.

Figure 13 presents an example of typical result from the FE model for Case 1. Table 9 summarises the results from the FE analyses.

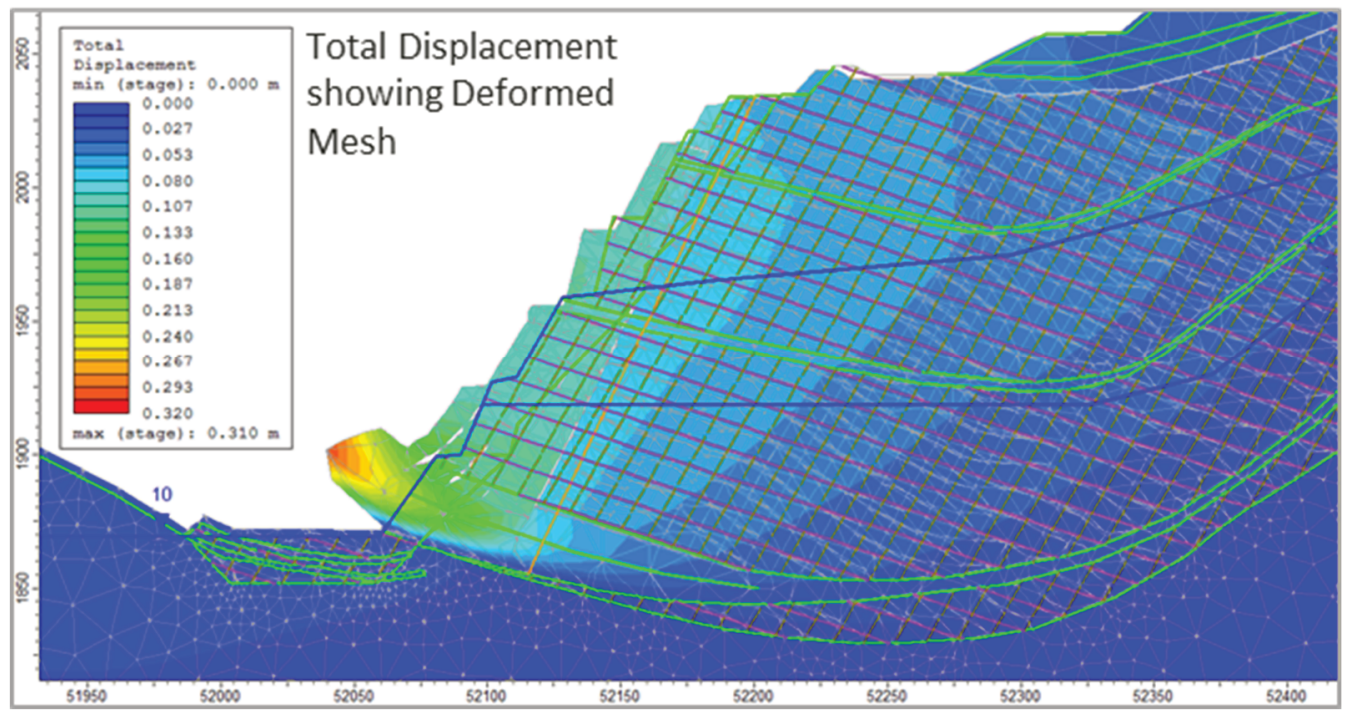

Figure 13 Example finite element modelling results for Case 1

Table 9 Summary of finite element results prior to exposure of weak coal seam

\begin{tabular}{|c|c|c|c|c|c|c|}
\hline \multirow[b]{2}{*}{ Case } & \multicolumn{2}{|c|}{$\begin{array}{l}\text { Pre-exposure of } \\
\text { weak coal }\end{array}$} & \multicolumn{4}{|c|}{ Post exposure of weak coal } \\
\hline & $\begin{array}{l}\text { Cumulative } \\
\text { displacement } \\
\text { (mm) }\end{array}$ & SRF & $\begin{array}{l}\text { Cumulative } \\
\text { displacement } \\
\text { (mm) }\end{array}$ & SRF & $\begin{array}{c}\text { Relative } \\
\text { displacement of } \\
\text { 010-Seam when } \\
\text { exposed in slope } \\
\text { face }(\mathrm{mm})\end{array}$ & Comments \\
\hline 1 & 141 & 1.3 & 310 & 0.7 & 189 & $\begin{array}{l}\text { Maximum deformation } \\
\text { occurs in the } 010 \text {-Seam, } \\
\text { bounded by west dipping } \\
\text { fault }\end{array}$ \\
\hline 2 & 163 & 1.1 & 340 & 0.7 & 193 & $\begin{array}{l}\text { Maximum deformation } \\
\text { occurs in the } 010 \text {-Seam, } \\
\text { bounded by west dipping } \\
\text { fault }\end{array}$ \\
\hline 3 & 149 & 1.2 & 386 & 0.7 & 260 & $\begin{array}{l}\text { Maximum deformation } \\
\text { occurs in the } 010 \text {-Seam, } \\
\text { bounced by west dipping } \\
\text { fault and discrete reverse } \\
\text { fault }\end{array}$ \\
\hline
\end{tabular}




\subsection{Finite element results discussion}

The results of the FE modelling indicate that the thick, weak coal seam at the toe was a key factor which contributed to the highwall instability. The modelling captured two potential and important failure modes: the first is related to deformation of the coal seam in association with the presence of a steep west dipping fault behind the slope, while the second incorporates the additional displacement associated with the presence of a moderately west dipping reverse fault.

The models show that significant deformation may have occurred in the weak seam when it was exposed during mining, leading to loss of confinement and strength, and subsequent retrogressive failure that propagated up the slope along a series of structural features. The results also show that varying combinations of rock structure in the wall could have contributed to the failure, including a discrete west dipping fault or out-dipping thrust faults.

The model displacement contours indicate the deformation is concentrated within the 010-Seam. The magnitude of deformation that can be captured by an FE model before it becomes unstable (i.e. non-convergent) is limited by the model mesh. Therefore, the FE models do not capture the full development of the global slope instability, but instead capture its initiation immediately following the excessive deformation of the 010-Seam at the slope toe. The deformation contours show displacement above the 010-Seam, but the magnitude of the displacement is generally lower than that observed in the GPS and radar data which capture the full failure displacements. The general shape of the deformed mesh and displacement contours generally represent the slope deformation observed visually (from still-photographs), and from the radar images which show the development of the horizontal boundaries corresponding to weaker materials. The eastern extent of the displacement contours at the slope crest approximately correlate to where the tension cracks were observed leading up to the failure.

The models representing the slope prior to exposing the weak coal had SRF values between 1.1 and 1.3, indicating stability prior to exposure of the seam. The deformed mesh of the models that simulate the slope prior to exposing the weak seam suggest that heave or bulging may have been noticeable in the pit floor as mining approach the 010-Seam; however, no record of floor heave was reported as this was not monitored.

The model that includes a discrete reverse fault daylighting within the weak seam (Case 3 ) shows the largest displacement when the 010-Seam is exposed, resulting from the contribution of both the fault and the seam deformations.

\subsection{Observations during continued mining following the P3 Pit failure}

Following the failure in the P3 Pit highwall, the slope below the failure was backfilled and mining continued to the north. Slope radar data collected during mining of the north section of the highwall showed up to $325 \mathrm{~mm}$ of deformation in the weak coal at the slope face, and during excavation of the north section of the wall. In addition, mining reportedly was occasionally temporarily suspended when outward bulging of the coal in the slope face was visibly noted.

\section{Implications for future highwall design}

Deformation of the 010-Seam during mining coupled with structure in the highwall was the likely cause of the P3 Pit highwall instability. The presence or absence of large-scale faults and systematic jointing, coupled with the sheared and structurally thickened, weak soil-like coal seam at the toe of the proposed P4 Pit highwall are critical considerations for wall stability. As the maximum height of the pit highwalls increases this could potentially lead to greater deformation within the weak coal seam. Deformation will likely occur during mining, even before the material is exposed in the slope face. The use of instrumentation such as slope radar, piezometers, and survey points were recommended for managing risk and detecting potential issues. The design of future highwalls may require a geotechnical berm, or step-out, at some elevation in the slope to decouple the overall slope into two separate inter-ramp slope areas, with a shallower overall slope angle. 
The absence of wall scale instability in the north section of the P3 Pit highwall may be due to the lack of the additional structures interpreted to bound the failure in the south wall section. Such observations and conclusions can be used to inform future highwall design, directing focus on identifying additional major structural features which may contribute to the development of multi-bench instability, where these are also associated with structural thickening (and associated shearing) of coal at the toe of the highwall slopes. This demonstrates the importance of identifying major structural features early in the mine design and planning process, and the need for robust and reliable geological and structural models.

\section{$9 \quad$ Limitations and uncertainty}

There are several sources of uncertainty and limitations in the models that could be reduced through further investigation or analysis. The deformation properties of the weak coal seam applied in the model have a high degree of uncertainty. Further site investigations (including in situ methods such as geophysics) could provide better estimates of deformation properties, which would allow for more meaningful deformation estimates. The potential presence of shallow, out-dipping reverse faults in the proposed P4 Pit highwall is not well understood based on the current available data. Further investigation using drilling or geophysical methods to target these features could reduce this uncertainty. The FE models were able to capture the initiation of failure within the slope but are not able to capture the ultimate failure event. Further work could be completed using more rigorous numerical modelling methods to simulate the post-failure displacements and runout. There is limited information available on the pore pressures in the slope at the time of the P3 Pit highwall failure.

\section{Acknowledgement}

Dr Ali Azizian and Dr Colin Fyfe provided their input to finite element modelling and interpretation of groundwater conditions, respectively. Dr Davide Elmo also provided guidance on the finite element numerical modelling. M. Peter Stacey provided review at critical stages of the project work, and guidance on important considerations that would not have been incorporated otherwise. Ms Tracy Krentz has persevered through the final formatting of this work with a consistently positive perspective, for which we are grateful. The staff at Teck Coal Limited and Teck Resources Limited continue to provide a collaborative working environment both internally and with their consultants, and it remains a pleasure to be working with them as a team.

\section{References}

Barnett, R, Azizian, A, Clayton, C \& Slater, M 2017, 'Geomechanical characterization of a sheared coal seam and implications for open pit slope design', Proceedings of the 51st US Rock Mechanics/Geomechanics Symposium, American Rock Mechanics Association, Alexandria.

Bieniawski, ZT 1976, 'Rock mass classification in rock engineering', Proceedings of the Exploration for Rock Engineering, A.A. Balkema, Rotterdam, pp. 97-106.

Elmo, D, Donati, D \& Stead, S 2018, 'Challenges in the characterisation of intact rock bridges in rock slopes', Engineering Geology, vol. 245, pp. 81-96.

Grieve, DA \& Price, RA 1987, Geological Setting of the South Half of the Elk Valley Coalfield Southeastern British Columbia. Preliminary Map 63. Ministry of Energy, Mines and Petroleum Resources, Geological Survey Branch.

Rocscience Inc. 2017, RS2, version 9.023, computer software, Rocscience Inc., Toronto. 
